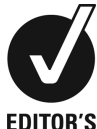

\title{
Tuberous sclerosis complex: multisystem hamartomas
}

\author{
Negar Naderi, Irina Timofte, Michael T McCurdy, Robert M Reed
}

Division of Pulmonary and Critical Care Medicine, University of Maryland, Baltimore, Maryland, USA

\section{Correspondence to} Dr Robert Michael Reed, rreed@medicine.umaryland.edu

Accepted 5 January 2015

\section{DESCRIPTION}

Tuberous sclerosis complex (TSC) is an autosomal dominant genetic disorder resulting in the growth of benign tumours or hamartomas affecting any organ system. Up to $90 \%$ of patients present with seizures due to growth of benign tumours in the brain. ${ }^{1}$ Although significant morbidity is associated with cardiac, renal and pulmonary involvement, the neurological aspects and particularly seizures associated with tuberous sclerosis are extremely difficult to treat. ${ }^{1}$ The hallmark cutaneous manifestations include ash-leaf spots (figure 1), angiofibromas, ungual fibromas, subungual red comets and splinter haemorrhages (figure 2). Up to $80 \%$ of patients also have renal tumours known as angiomyolipomas (figure 3) which can result in spontaneous aneurysmal bleeds and haemorrhagic shock due to formation of abnormal vasculature. ${ }^{12}$

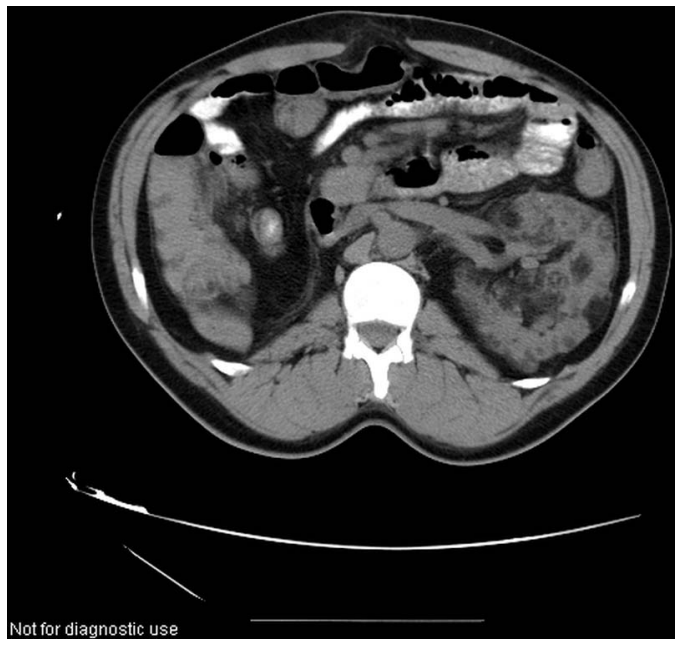

Figure 1 Angiomyolipoma: cortical kidney tumours composed of abnormal vascular formations, smooth muscle and fat (hypodense on CT imaging).

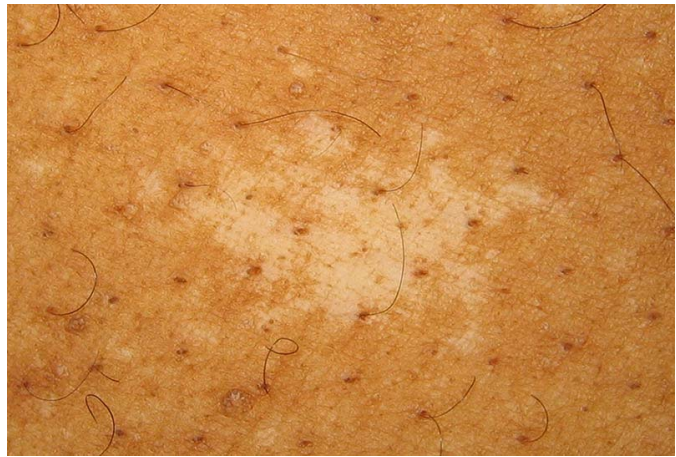

Figure 2 Hypopigmented, diamond-shaped macules known as ash-leaf spots, along with angiofibromas are cutaneous manifestation of tuberous sclerosis.

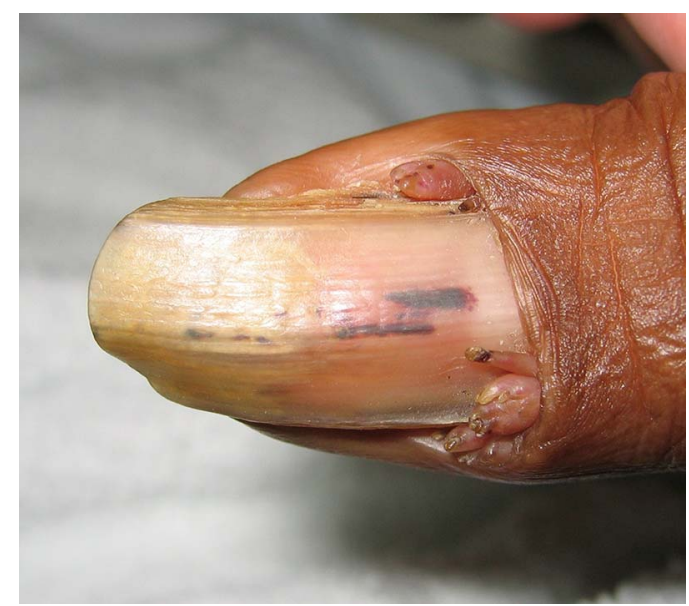

Figure 3 Splinter haemorrhages, periungal and subungal fibromas occur generally in adolescence or adulthood and are more common on the toes than the fingers.

TSC is caused by mutations in either the TSC1 or TSC2 genes. TSC1 and TSC2 form a complex responsible for the regulation of the mammalian target of rapamycin complex 1 (mTORC1). ${ }^{1}$ Drugs that inhibit mTORC1, such as sirolimus and everolimus, have demonstrated efficacy for the treatment of multiple aspects of TSC, including renal angiomyolipomata, refractory epilepsy associated with brain tumours, and lymphangioleiomyomatosis. ${ }^{2}$

\section{Learning points}

- Tuberous sclerosis complex (TSC) is an autosomal dominant disorder with an incidence of 1:6000 births.

- TSC is caused by mutations in the TSC1 or TSC2 genes needed for the normal expression of the mammalian target of rapamycin (mTOR) pathway. $^{12}$

- TSC results in the growth of benign tumours (hamartomas) affecting any organ in the body; brain and cognitive abnormalities are the most common manifestations of the disease and most patients present with epileptic seizures during infancy.

- Surgical resection is the standard treatment for those with neural lesions and refractory epilepsy; however, everolimus (an mTOR inhibitor) has shown promise in the treatment of those not amenable to surgical resection or those with renal involvement of the disease. ${ }^{2}$ 
Contributors All authors meet ICJME criteria for inclusion on this manuscript as authors.

Competing interests None.

Provenance and peer review Not commissioned; externally peer reviewed.

\section{REFERENCES}

1 Crino PB, Nathanson KL, Henske EP. The tuberous sclerosis complex. N Engl I Med 2006;355:1345-56.

2 Franz DN. Everolimus in the treatment of subependymal giant cell astrocytomas, angiomyolipomas, and pulmonary and skin lesions associated with tuberous sclerosis complex. Biologics 2013;7:211-21.

Copyright 2015 BMJ Publishing Group. All rights reserved. For permission to reuse any of this content visit

http://group.bmj.com/group/rights-licensing/permissions.

BMJ Case Report Fellows may re-use this article for personal use and teaching without any further permission.

Become a Fellow of BMJ Case Reports today and you can:

- Submit as many cases as you like

- Enjoy fast sympathetic peer review and rapid publication of accepted articles

- Access all the published articles

- Re-use any of the published material for personal use and teaching without further permission

For information on Institutional Fellowships contact consortiasales@bmjgroup.com

Visit casereports.bmj.com for more articles like this and to become a Fellow 